\title{
Skill Training Models to Install and Maintain for House Electrical Installation
}

\author{
J. Kustija, E. Mulyana, B. Trisno, Hasbullah \\ Department of Electrical Engineering Education \\ Universitas Pendidikan Indonesia \\ J1. Dr. Setiabudhi 207 Bandung, Indonesia \\ jaja_kustija@yahoo.com
}

\begin{abstract}
This research aims to develop a training model on installation and maintenance of electrical installations homes for youth in the village. The research using activities carried out by using participatory approaches demand responsive approach method. Training model development is based on the needs and potential of the community and local village in the context of development and sustainability, the goal of this training can provide job opportunities for the youth in an effort to reduce unemployment. Skills training model development include: (1) the planning stage (need assessment), (2) the implementation stage, (3) mentoring phase and (4) monitoring and evaluation. The results of the training model of the installation of electrical developers are opening business opportunities for the youth in electrical installation so as to improve the standard of living and well-being as well as the establishment of a model village built supported by the village government officials with PKM teambased partnership with UPI. PKM activity guided village-based partnership was attended by about 35 youth who are representatives of each pillar citizens to be given training and assistance in the installation and maintenance of residential electrical installation. The output of Entrepreneurship PKM is the emergence of a cadre of independent village installer from among the youth who mastering the skills of installation and maintenance of electrical installations of residential houses. Another outcome of this Patronage village PKM activity is the publication of articles or scientific publications in national or international journal.
\end{abstract}

Keywords-training model; electrical instalation; job opportunities; youth

\section{INTRODUCTION}

West Bandung regency development and population growth are increasing very rapidly either by birth or urbanization, demanding the development of the district both for residential and industrial area. But because West Bandung regency is geographically located in the capital city and the provincial capital of the state. The construction of dwellings in West Bandung regency until now still growing, growth is increasingly causing overcrowding and the increasing number of homes and of course this raises a lot of problems if it is not organized as possible.

As for the youth who living the Sukajaya village, Lembang has a problem in developing skills, this occurs because of the lack of coaching skills to youth in Sukajaya, so they are difficult to work and that the unemployment rate in Sukajaya still relatively large. To improve the situation, the need for community development, training is given in an effort to improve the ability of citizens to cope with the demands and changes in the surrounding environment. Provision of training aimed at empowering the community, so that citizens become empowered and able to participate actively in the process of change. Training can help people or communities to apply knowledge and skills already possessed. With training can also lead to changes in working customs society, a change of attitude towards work, as well as in information and knowledge which they apply in their daily work. Training activities can occur if a person or community realized the need to develop the potential and ability to meet the needs and satisfaction of life, therefore it is necessary empowerment activities.

Utilization of electrical energy has become the primary requirement for any modern society. Almost every building requires electrical energy that can support human activities such as home, school, office, and so on. [1]. Seeing the electrical energy consumption is growing in the community, especially the use of electrical energy lighting, we need a system that is a good electrical installation and safe to avoid the dangers that can arise.

Electrical installation work inside or outside the house or building must comply with these rules, so that the installation is safe for use in accordance with the intent and purpose of use, easily serviced, and easy to maintain. Designers, installers and inspectors electrical installations must comply with the safety and health of its workforce in accordance with laws and occupational safety and health regulations in force, [2].

Electrical installations are generally always used in every residence, this would make an opportunity for people to have the skills, the training activities Installation and maintenance Installation of Electrical Household Living Quality of electrical installations here depend on the implementation and application of the standard rules of electrical installation including General Regulations Electrical installations and other regulations that support. The purpose of the application of these rules is to ensure the safety of humans, livestock and property, as well as the main condition of electricity supply can be carried out safely, reliably and familiar environment [3]. Over time and growing electricity needs of the community, household lighting installation is also changing both in quality 
and in quantity. The decreasing the quality of the electrical installation, and change the quantity of the load point, as a result of changes in both greatly affect the feasibility of the installation and the safety of the wearer. It can be estimated that in general the customers are not experts in the field of electricity. A result of inadequacy of the installation can cause an accident such as a short circuit or arching [4].

As if seeing the location of the fire that largely occurred in residential and business premises, meaning fires can be caused by human error factor, it is because of its lay people to the knowledge of the use of electricity so often acted inadvertently or negligent in using electric current or did not follow the proper procedures and methods in accordance with the applicable rules. Due to the short-circuit currents may cause little fires cause losses for both property and lives. One of the efforts that could be made to suppress the fires is the use of wiring and safety in accordance with good standard mounting area and the capacity of applied voltage [5]. By looking at this it required an effort to raise awareness of contractors and installers who are authorized in the electrical installation, which should really pay attention to the use of standard equipment electrical installation and correct connection system, must follow the rules set by the government [6].

\section{METHOD}

When referring to the interest of the program PKM village of Patronage, this activity is a form of social development that endeavor to the efforts of community empowerment, where this concept philosophically stressed to the process of providing, or divert some power, strength or ability to individuals or groups of individuals and society itself in order to become more empowered. It emphasizes the efforts to stimulate the process, encourage and motivate individuals to have the ability or the empowerment to determine what is becoming live choice. Departing from these assumptions, the methodological programs this service will use the methodology of Participatory approaches Demand Responsive Approach.

Guided village PKM program will be developed based on the needs of local communities and villages in the context of development. Experience shows that good plan is made based on participatory assessment or evaluation of the particular situation. Participatory planning is understood better reflect the reality in the field and the way can involve local people in bringing them to responsibility either in the present or in the future. People do not always have the same perception and vision of a problem, because they come from different cultural backgrounds and have priority environmental interests and different life. Planning of participation is a step to establish a common understanding of the issues. Plan participation is simple, democratic and generate motivation, innovation and creativity among the citizens. The method provides the opportunity for community groups to reach an agreement given situation. Development activity in a participatory manner which will be designed by "Team Community Service" This is one way to increase the participation of all actors involved to think and contribute to the activities and phasing of development in the Sukajaya, Kabupatan Bandung Barat as an area that will be developed into " Patronage village "by LPPM UPI. Theoretically participatory methodology will give an opportunity to the community to cooperate actively premises of community facilitators from initial planning, activity implementation to monitoring and evaluation stages. The public will be actively involved in mapping problems and potential as well as new ideas that will help the community itself in conducting-activities in the future. It aims to get together the people learn the circumstances that exist related to the program that will be carried out, and then look for solving real problems.

To build and print the young cadres who have skills in the field of electrical installations carried out a phased approach that can stimulate the mental, among young people and youth, which is as follows:

First Step, aims to make youth understand deeply the basic of an electrical installation, from the ability to identify equipment and major components of electrical installation, how to make a lines diagram (one line diagram) of simple installation, and apply in real terms of the diagram of the line into the picture implementation. Analytical skills and creativity of the target audience is honed and nurtured in the process of this intervention in order to obtain optimal results.

Second Step, intended for youth to learn how an installer can applying skills planning begins with charting, diagramming implementation and budgeting plan that will determine the costs to be incurred. To convince a third party in order to realize the program we had planned then the participants must be committed to what you want to achieve in the future to always look for ways to achieve that goal; a partnership with a third party.

Third Step, is to encourage independent cadres who have the skills of electrical installations and provide business opportunities for youth and youth in the field of electrical installation so as to improve the standard of living and wellbeing. Therefore, need good networking among the cadres with village officials concerned and certainly with the community around the village area Sukajaya District of valley district. Bandung West so as to determine the added value through targeted market research together.

Fourth Step, is the process of stabilization and expansion plan forward in electrical installations. For long-term goals, sustainability coaching program then proposed the establishment of electrical installations field as a platform for developing products and services in the field of electrical installation residence. Besides, it should be considered to establish a model village built in the district of West Bandung regency valley especially for village self-sufficient in terms of installation and maintenance of electrical installations are supported by government officials with the village government based on partnership with Team PKM LPPM UPI.

\section{RESULT AND DISCUSSION}

This study on the activities of the steps taken to develop the skills of people in the field of electrical installation. The activity starts from the preparation stage to the stage of monitoring and evaluation. More details stages are: 


\section{A. Preparation}

In accordance with the objectives of the program PKM Village Patronage-Based Partnership with the theme Training Installation and Maintenance of Electrical Installations House Live For the Youth and Youth in Sukajaya, so at this stage the team PKM socialization activities widely to the target audience in this case the youth and youth in the Village area Sukajaya Lembang district. The youths who participated in the training are mostly those which represent a particular region or Pillars of Citizens (RW) and have a desire to acquire knowledge and skills on how to install and maintain electrical installations home stay well and meet the standards set.

At this stage, collected as many as 25 young people who are delegates or representatives of various Pillars of citizens (RW) in the Village area Sukajaya. All participants will be trained and guided to master the skills in the field of installation and maintenance of electrical installations, especially electric homes to be trained by instructors who have experience of TIM PKM UPI.

All participants will later be given training on how the technique connecting cable is good, the technique connects the cable to the load (lamp) which is electrified and can use the various components of the electrical installation so to be a series of installation is good and right in accordance with the standards and safety.

\section{B. Implementation}

In this second phase, all participants that have been selected and have the potential to master the technology of electrical installation given intensive training guided by instructors from the village PKM UPI team. The training was held in the village hall Sukajaya Lembang district KBB during several meetings was followed enthusiastically by the participants were mostly young and administrators of youth in Sukajaya, so hopefully they can be cadres fitter self can provide his skills to the surrounding community.

At this stage also Entrepreneurship teams and assisted by instructors from students to provide guidance to youth and youth by conducting training on installation and maintenance of electrical installations well and provide guidance on how the opportunities to develop the skills of the installer is to serve as business that can prop up the economy family.

\section{Assistance}

As a follow up to the stage of training the post-training mentoring process continues to be given to participants. The participants continue to be monitor progress and PKM team Patronage UPI village in intensive, so that participants get the assistance and technical assistance in the field directly from an experienced instructor.

During the period of this participant assistance also given the cases relating to installation is good and right. To determine the extent of the development of the participants to absorb the knowledge and skills that have been learned, the instructor gives a direct case to be done by the participants of the repair electrical installations Building sport (GOR) in the Village Hall. The stages of further activities before the participants deployed to the field of participants was given the task of maintaining and repairing the installation of sport building in Sukajaya and do installation the plant as part of a re-test of the ability or the competence of the trainees are still accompanied by the instructor PKM UPI.

Continuing the process of assistance to the participants that youth and youth in order to improve and develop the mastery of technique installation skills and maintenance of electrical installations of residential houses. For those who already have sufficient proficiency and skill, the team will bring in a team of association of electrical and mechanical contractors in Indonesia (AKLI) to give the exam/ test for those who are ready and provide a certificate of professional expertise for participants who have passed the exam will be given. By holding licenses in the field of professional expertise installer is expected that participants are more confident to apply the skills possessed and surrounding communities will not shy-hesitate to use their expertise when there are problems on residential electrical installations.

\section{Monitoring and Evaluation}

Monitoring and evaluation (M\&E) is done in stages, well before the training activities carried out, during the implementation or after training on installation and maintenance of electrical installations of residential houses. M $\& \mathrm{E}$ is done primarily to determine and quantify the extent of progress made by the trainee in mastering the theory and application of the installations so that the team can assess the extent PKM success rate of activities that have been implemented and the target of what to expect. Evaluations were conducted in the village PKM Patronage This partnership-based form of direct discussions with youth and youth are nurtured and also discussions with the faculty team PKM. What are the difficulties in implementing these activities and solutions to overcome them. Participants also continues to provide valuable inputs to the faculty team that PKM activity Patronage village can run well. Follow-up of development activities are conducted in the form of/ capacity building skills of youth and youth about the business opportunity to open the center of electrical installation into a container for gathering of village cadres independent installers.

Based on the results of monitoring and evaluation of a number of cadres were trained to become fitter village has a role to assist the village in seeking improvements and electrical installation of residential houses in the village area Sukajaya. PKM team asses and selecting choose about seven cadres installer are ready to be deployed to help the village to the problems associated with electrical installations.

That activity of PKM village built is sustainable and cadres that has been nurtured to be useful, it needs to be done ahead of trainees will be collected in a community forum cadres installer incorporated in business installers center that will be accommodated by the local village government local to equally build village and can create electrical energy independent village. 


\section{CONCLUSION}

Community service activity based on village-based partnership has been implemented successfully. The results of the activity are:

1. Perception and awareness in terms of installation and maintenance of electrical installations of residential houses should be a concern of all parties, because generally people not many people know the importance of maintaining the security and safety of electrical installations installed dangers if it does not meet the standards set.

2. Skills in terms of the electrical installation for the youth in the region can be one of the solutions to reduce unemployment and create jobs/ new entrepreneurs for the people so that the living standard of local residents and the economy to be increased.

3. In order to create an energy independent village especially electrical energy, then should any region or village has become a mainstay cadre installer village in problem associated with the installation and maintenance of electrical installations.
4. The Role of Universities in providing knowledge and motivate each region or village needs to be improved so that the directional pattern of rural development and the creation of a model village built that are expected to materialize.

\section{REFERENCES}

[1] Mustika I, Timotius C, Hasbullah, 2013, Aplikasi Perencanaan Perhitungan Instalasi Listrik Penerangan Menggunakan Sistem Pakar. Jurnal Elektrans Teknik Elektro FPTK UPI. Volume. 12 No.1 Maret 2013.

[2] Badan Standar Nasional, 2000, Persyaratan Umum Instalasi Listrik (PUIL). Badan Standar nasional. Jakarta.

[3] Suyitno.M. 2008. Pemeliharaan Instalasi Listrik Rumah Sederhana. FTUNJ, Jakarta.

[4] Alfith. 2013. "Kelayakan Instalasi Listrik Rumah Tangga Dengan Pemakaian Lebih Dari 10 Tahun Di Kanagarian Nanggalo Kecamatan Koto Xi Tarusan Kabupaten Pesisir Selatan”. Jurnal Teknik Eletro ITP, Volume 2 No. 2; Juli 2013.

[5] Harten P.V. Setiawan E. 1985. Instalasi Listrik Arus Kuat Jilid II. Bina Cipta. Bandung.

[6] Suryatmo, F., 1998. Teknik Listrik Instalasi Penerangan. PT.Rineka Cipta.Jakarta. 